\title{
BIOCHEMICAL CHANGES OF MERCURY CHLORIDE ON BLOOD METABOLITE LEVELS OF A FRESHWATER FISH, LABEO ROHITA
}

\author{
Lekeshmanaswamy, M*., K. Anusiya Devi and C.A. Vasuki \\ PG and Research Department of Zoology, Kongunadu Arts and Science College, Coimbatore \\ *E.mail: ml_swamy64@yahoo.co.in
}

\begin{abstract}
Rohu (Labeo rohita) is a fish of the carp family Cyprinidae, found commonly in rivers and fresh water lakes in and around South Asia and South - East Asia. The freshwater fish Labeo rohita were exposed to Mercury chloride $(0.25 \mathrm{ppm})$ for 10,20 and 30 days and its effect on blood - bio chemical properties in the form of hyperglycemia, hypoproteinemia and hypercholesteromia. The results of the present study that the blood - biochemical changes may lead to the fish morbidity and mortality.
\end{abstract}

Keywords: Labeo rohita, blood glucose, serum protein and serum cholesterol.

\section{INTRODUCTION}

Water is the home of the fish and its quality is one of the most over looked aspect of pond management until it affects fish production. Water quality generally means the component of water which must be present for optimum growth of aquatic organisms (Ehiagbonare and Ogundiran, 2010). Heavy metals have been announced to exert a vast range of metabolic, physiological, ecological and behavioral influences on fish (Soengas et al., 1996). Mercury is non biodegradable and non advantageous heavy metals and their role in the cell is not understood (Bailey et al., 1999). It enters the food was through bacteria, algal and fishes of freshwater and marine water etc. as compared to land animals (Gupta, 1998). Examinations on the toxic effect of metals on fish are joined by the analysis of exchanges in some haematological and biochemical blood indices (Hoyle et al., 2007).

\section{Objectives}

$>$ To observe the $\mathrm{LC}_{50}$ concentration of mercury chloride to the fish, labeo rohita

$>$ To observe the effect of sublethal concentration of Mercury chloride on biochemical characteristics in blood of the fish, labeo rohita

\section{MATERIALS AND METHODS}

\subsection{Experimental fish - Labeo rohita}

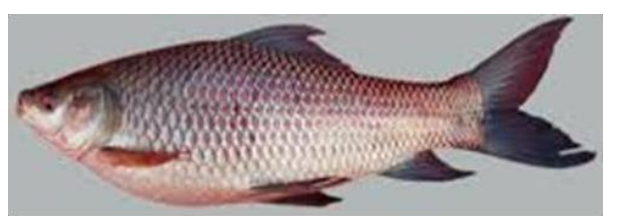

\subsection{Test toxicant - Mercury chloride}

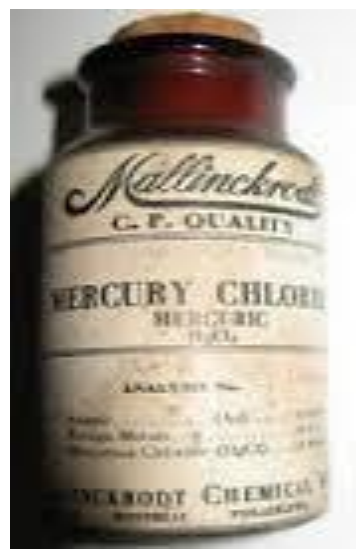

A static bio - assay test was done to determine $\mathrm{LC}_{50}$ of Mercury chloride to Labeo rohita following the method of APHA (1985) and sublethal concentration was calculated by adopting the formula of Hart et al. (1945). For each experiment the fish (average length $8-8 \mathrm{~cm}$ and wt. 26-28gm) were exposed to a sublethal concentration of mercury chloride ( $0.25 \mathrm{ppm}$ ) for a period of 10,20 and 30 days. Side by side a control was also run in equal volume of water. The exposure medium was renewed every 24 hours. At the end of exposure period $(10,20$ and 30 days $)$ the fish were anaesthetized with 1:4000 MS 222 (tricane methane sulphonate sandoz).

* Estimation of blood glucose : Sinha (1990)

* Serum protein

: Varley et al. (1980)

* Serum cholesterol (1966)
: Karbara's method 


\section{RESULTS AND DISCUSSION}

The fish Labeo rohita under 10, 20 and 30 days exposure of mercury chloride shows hyperglycaemic, hypoproteineric and hypercholesterolenic response. The blood glucose level elevated to $80.62 \pm 1.5 \mathrm{mg} / 100 \mathrm{ml}$ of blood against the control value of $50.76 \pm 3.9 \mathrm{mg} / 100 \mathrm{ml}$. The amounts to an increase by $58.82 \%$ (Table 1). The protein depletion shows hypoproteinemia which depleted to $3.83 \pm 1.4 \mathrm{~g} / 100 \mathrm{ml}$ of blood against the control value of $7.15 \pm 0.37 \mathrm{~g} / 100 \mathrm{ml}$ of blood. The amount decrease by $46.43 \%$ (Table 1 ). The serum cholesterol elevation shows hypercholesterolemic response which elevates to $289.4 \pm 2.08 \mathrm{mg} / 100 \mathrm{ml}$ of blood against the control value of $247.5 \pm 0.37$ $\mathrm{mg} / 100 \mathrm{ml}$ of blood. This amount are increased by $16.92 \%$ (Table 1 ).

\subsection{Blood glucose}

Rita \& Milton et al. (2006) observed hyperglycemia in fish. The increase in the blood sugar level under 30 days treatment might be because of stimulation of a cells of islet of Langerhan's which secrete and much amount of glucagons in turn had an action upon liver glycaogen with consequent enhanced glycogenolysis and the resultant hyperglycemia.

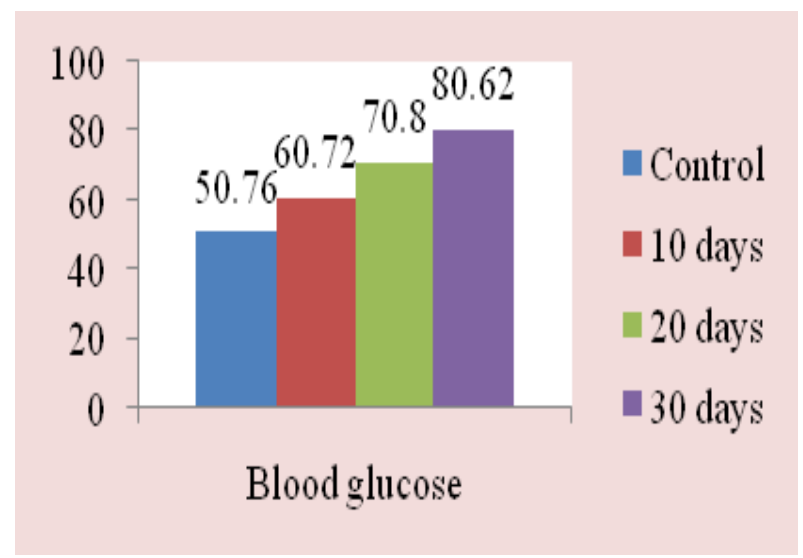

Fig. 1. Changes in the blood glucose levels in Labeo rohita exposed to sublethal concentration of mercury chloride.

Table 1. Changes in the blood metabolite levels in Labeo rohita exposed to sublethal concentration of mercury chloride.

\begin{tabular}{lcccc}
\hline \multicolumn{1}{c}{ Parameter } & Control & 10 days & 20 days & 30 days \\
\hline Blood glucose $(\mathrm{mg} / 100 \mathrm{ml})$ & \multirow{2}{*}{$50.76 \pm 3.9$} & $60.72 \pm 0.8$ & $70.80 \pm 0.9$ & $80.62 \pm 1.5$ \\
\% change & & $+19.62 \%$ & $+39.47 \%$ & $+58.82 \%$ \\
Serum protein $(\mathrm{g} / 100 \mathrm{ml})$ & $7.15 \pm 0.37$ & $6.25 \pm 0.4$ & $4.45 \pm 0.8$ & $3.83 \pm 1.4$ \\
\% change & & $-12.58 \%$ & $-37.76 \%$ & $-46.43 \%$ \\
Serum cholesterol $(\mathrm{mg} / 100 \mathrm{ml})$ & $247.5 \pm 0.37$ & $265.0 \pm 1.6$ & $276.8 \pm 1.9$ & $289.4 \pm 2.08$ \\
\% change & & $+7.07 \%$ & $+11.83 \%$ & $+16.92 \%$ \\
\hline
\end{tabular}

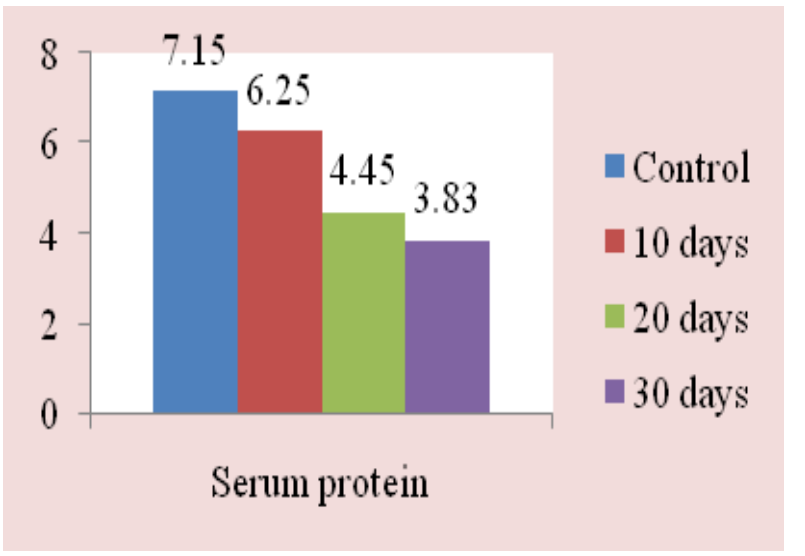

Fig. 2. Changes in the serum protein levels in Labeo rohita exposed to sublethal concentration of mercury chloride.

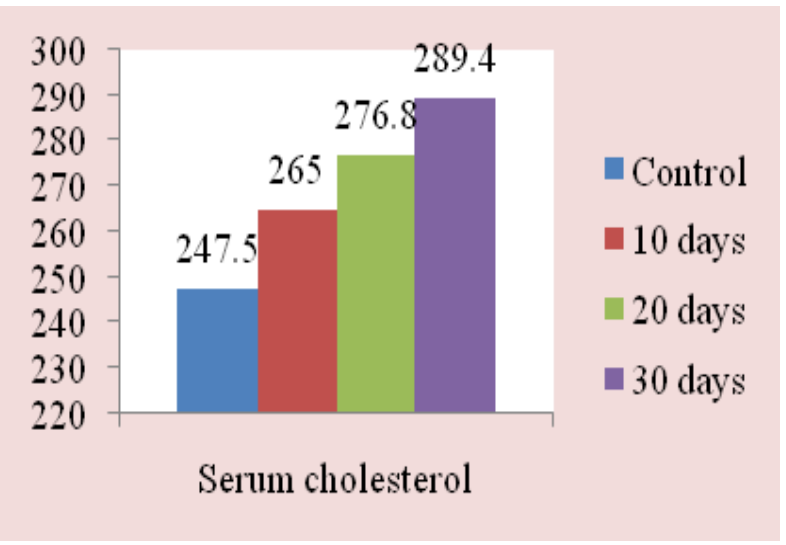

Fig. 3. Changes in the serum cholesterol levels in Labeo rohita exposed to sublethal concentration of mercury chloride. 


\subsection{Serum protein}

Rekha Rani et al. (2008) observed hypoproteineric in fish. The liver cells might have reduced or stopped the synthesis of serum protein due to direct toxic effects of the mercury chloride and the serum protein would have been utilized under heavy metals induced stress leading to their depletion.

\subsection{Serum cholesterol}

Rekha Rani et al. (2008) observed hypercholesterolenic in fish. This might be attributed to the utilization of the volatile fatty acids by damaged liver parenchyma and ultimate entry to the circulation or to decreased excretion of cholesterol by damaged liver.

\section{CONCLUSION}

Mercury chloride proved to be highly toxic at sublethal concentration of $0.25 \mathrm{ppm}$ where $100 \%$ mortality was observed after 60 days exposure. The results of the present study that the blood biochemical changes may lead to the fish morbidity and mortality.

\section{REFERENCES}

American Public Health Association, (1985). Standard Methods for the Examination of Water and Wastewater.

Bailey, S.E., T.J. Olin, R.M. Bricka and D.D. Adrian, (1999). A Review of Potentially Lowcost Sorbents for Heavy Metals. Water Res. 33: 2469-2479.

Ehiagbonare, J.E. and Y.O. Ogundiran, (2010). Physico - chemical analysis of fish pond waters in Okada and its environs, Nigeria. Afr. J. Biotech. 9(36): 5922-5928.
Gupta, V.K., (1998). An overview of heavy metals: Impact and remediation. Res. J. Chem. Environ. 2: 63-66.

Hoyle, I., B.J. Shaw and R.D. Handy, (2007). Dietary Copper Exposure in the African Walking Catfish, Clarias Gariepinus: Transient Osmoregulatory Disturbances and Oxidative Stress. Aquatic Toxicol. 83(1): 62-72.

Rekha Rani, R., K. Gautam and Suneel Kumar, (2008). Toxicity of Nuvan on Kidney cholesterol on Labeo rohita. Ind. J. Environ. Ecoplan. 15(1-2): 115-118.

Rita, J.J.A. and M.C.J. Milton, (2006). Effect of carbamate pesticide (methomyl) on the biochemical components of the freshwater Oreochromis Mossambicus (Peters). Ind. J. Environ. Ecoplaning 12(1): 263 - 268.

Sinha, et al. (1990). Manual of practical Biochemistry scientific book company, Patna.

Soengas, J.L., M.J. Agra-Lago, B. Carballo, M.D. Andres and J.A.R. Veira, (1996). Effects of an Acute Exposure to Sublethal Concentrations of Cadmium on Liver Carbohydrates Metabolism of Atlantic Salmon, (Salmo Salar). Bull. Environ. Contamin. Toxicol. 57(4): 625-631.

Varley, H., A.H. Gowenlock and M. Bell, (1980). Practical Clinical Biochemistry, 5th Edition, William Hienemann Books Ltd., London.: 550.

Kabara, J.J., (1986). Determination and microscopic localization of cholesterol in method of Biochemical analysis (ed.D.Glick) New York. Inter Science Publishers, Inc. 263-318. 